\title{
Leading in the certainty of uncertain times
}

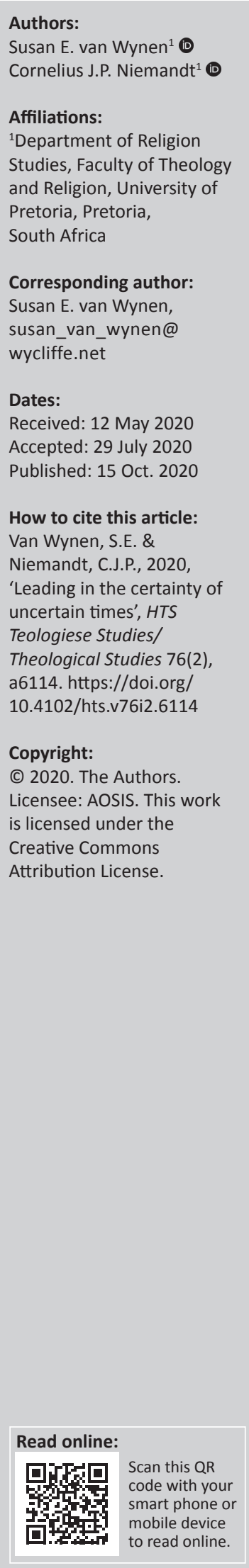

This research focused on the potential for Christ-following leaders to develop a theological and missiological posture in response to the current volatile, uncertain, complex and ambiguous (VUCA) world context. This research looks at how the attitudes and actions of the corporate world have influenced those of Christian organisations and Christian leadership. The corporate world primarily focuses on strategies for overcoming the challenges of the VUCA environment, but this research explores how Christ-following leaders might benefit from looking more deeply at what VUCA represents, rather than merely accepting and reacting to it. The research used a literature review to develop the groundwork for an increased understanding of how God and VUCA relate and how Christ followers can develop a perspective in keeping with an understanding of God's mission, their calling and the VUCA world mindset. Although some research has been done regarding spirituality as part of a response to the VUCA world, it has often focused on the outward expressions (morality, values, collaboration and service) with little attention to the Christ follower's source of spiritual life, the trinitarian God. This research integrates recognition of the character of God, evaluation of VUCA realities and rhetoric, and the responsibilities and opportunities of leaders who desire to participate in God's mission. In this process, the research explores strategy metaphors, missional thinking and leadership implications.

Contribution: This research encourages greater theological and missiological exploration of the Christian leader's posture and response to the VUCA world mindset. The research engages with corporate thinking regarding strategy and the implications of VUCA and with theological and missiological thinking regarding God's role, the leader's role and the nature of current contexts, both local and global.

Keywords: Volatility, uncertainty, complexity, ambiguity (VUCA); Mission of God; Change; Strategy; Metanarraphor; Journey concept; Discernment; Missional intent.

\section{Leading in the certainty of uncertainty}

Writing during the onset of coronavirus disease 2019 (COVID-19) in my own community and knowing that colleagues around the world are in the same situation, or worse, it could be difficult to know how to address readers, even those of the near future. However, why should it be more difficult than usual? This topic and title were chosen long before the pandemic. We always live in uncertain times. We are, perhaps, just more aware of it at the moment.

Today there are new contexts, new conflicts and new concerns that make the unsettledness across the globe seem new as well. This article looks at how Christ-following leaders can reflect on and respond to their current and future contexts. How should Christian leaders and organisations respond to the concept that the world can be described as volatile, uncertain, complex and ambiguous (VUCA)? Books and articles in the corporate world primarily focus on how to keep a business alive and growing in spite of VUCA. However, the VUCA-related advice for leaders is remarkably similar to all the other leadership advice of the past 30 years. The thesis of this research is that the Christ-following leader has the potential and responsibility for a posture and response that reflect a distinctively different perspective regarding the VUCA world mindset.

This research serves merely as an introduction to one facet of exploring a holistic theological and missiological foundation for leadership in current and future contexts. The particular context of this research was within the Wycliffe Global Alliance. The Alliance is a community of more than 100 diverse organisations and networks serving together in Bible translation movements around the world. The Alliance has sought to increase and deepen its understanding of participation in God's mission through missiological conversation, nurturing of community and a commitment to

Note: Special Collection entitled Christian Leadership, sub-edited by Wessel Bentley (UNISA). 
journeying with Christ. This journey concept permeates both philosophical and practical aspects of Alliance thinking and behaviour (Van Wynen 2020). The goal of this particular article's contribution is to explore the question: How does/ can the nature and presence of God impact how Christfollowing leaders think about and respond to the challenges presented by the VUCA world mindset?

\section{Introduction to the VUCA world}

The corporate world adopted the acronym VUCA to describe today's world. The acronym was coined by the US Army to describe the post-Cold War world (Tovar 2016). New wars and enemies brought new questions and challenges. The world seemed, somehow, even less stable and secure. Forsythe, Kuhla and Rice (2018) state that the concept of VUCA has since been embraced:

$[B] y$ leaders in all sectors of society to describe the nature of the world in which they operate: the accelerating rate of change (volatility), the lack of predictability (uncertainty), the interconnectedness of cause-and-effect forces (complexity) and the strong potential for misreads (ambiguity). (n.p.)

One could argue that VUCA has always been with us. The University of Bologna, Italy, originating in 1088 and founded as a university in 1563 , is considered the oldest university in the Western world (University of Bologna n.d.). Their Military Architecture Museum in the Palazzo Poggi has a remarkable exhibit of fortification plans designed and built by the most eminent Italian, German and French engineers of their day. The intricately inlaid wooden panels are strikingly beautiful. Because the forts are depicted from an aerial perspective, the panels resemble puzzles of Christmas stars. However, they are, in fact, models of actual or proposed fortresses and strongholds. Studying these models, one can track architectural improvements and modifications through the years. These panels were also an important tool for the study of town planning. For centuries, the fortresses they depict protected kingdoms and countryside. However, there came a day when soldiers with shovels, catapults, cannons and eventually airplanes could reduce these strategically designed and positioned fortresses to ruins. Certainty is fragile and temporal. And the certainty of one era is the rubble of the next.

History offers much evidence of a VUCA world. Politics, economics, natural disasters and diseases altered kingdoms and nations over the centuries ... or sometimes, overnight. The Bible offers many historical examples of the VUCA nature of the world. From Adam's fall to the persecution of the early church, there is evidence of a world unsettled. Abraham, Joseph, Moses, David and a long list of prophets and ordinary people could identify with a VUCA world context of change, turmoil and power shifts. In many ways, the world has always been VUCA. It may just be more obvious in some places, some eras.

Responses to today's VUCA world have engendered a powerful sense of urgency and a seemingly endless drive for innovation, particularly technological. However, historian
Ian Mortimer cites the tremendous changes in each century of the past millennium and points out that, whilst technology and change are related, the more important factor in every era is how change and human need are related (Mortimer 2014). Mortimer's observations invite us to look deeper and ask, 'what needs are represented by the current VUCA environment?' Are present-day responses to VUCA meeting those needs, or are they just further symptoms of deeper needs unmet?

Humans seek safety, certainty. When those things are in question, a sense of anxiety, or at least urgency, prevails. However, few things are truly certain. This is a dilemma for leaders. Leaders are supposed to rise to challenges, ease anxiety and show the way forward. Kotter refers to this leadership role as 'aligning' people to a vision, in contrast to the managerial task of 'organizing' people into precise and efficient systems. Leadership is about direction setting (Kotter 1999:57-58). Leaders are expected to promote change and to move their business and their people forward toward that vision. However, even 20 years ago, business guru Warren Bennis questioned the value of leaders initiating change strategies because of the unpredictable nature of the world and the many variables involved (2000:302). Deep down, leaders know the day will come when what is working well does not work anymore. In the course of history, the leaders of nations experience that day. The leaders of corporations, churches and non-profit organisations face that day. In ancient and recent history, that day came in times of war, disease, political unrest and economic depression. For many it came in 2020. In some ways it comes every day, in situations both large and small.

\section{Guiding assumptions}

It could seem presumptuous to make any assumptions when talking about a world that is volatile, uncertain, complex and ambiguous. However, it is, in fact, all the more essential to determine a starting point. For the purpose of this discussion we will start from the premise that we are primarily addressing followers of Christ. We are also starting from the premise that God has a mission to redeem and restore his creation, and that he has invited and called those who follow him to participate in that mission (Wright 2006). This also assumes that because he is God and it is his mission, he is in control. Bosch stated that mission was an 'action in hope' because it is based on God's action in the world and our 'participation in the missio Dei' (1991:498). Christopher Wright puts it very clearly: 'Mission is not ours, mission is God's' (2006:62). Based on this understanding, leaders in churches and Christian organisations can and should have a different perspective from other leaders when encountering a seemingly VUCA environment and when contemplating strategy. Many people try to fight it, ignore it, control it, market it or manipulate it. Some promote tackling it as a whole (Gruwez 2017); others advise approaching each facet individually: 'You don't fight VUCA, you fight $V$ and U and C and A' (Kail 2011). Followers of Christ need not follow the trends of how to think about and respond to the challenges of VUCA. However, they must 
identify what VUCA really is and what it means in their context, and then lead others through it. Not to emerge on some 'other side', at least not in this lifetime, but to be better prepared and better equipped to keep going. The VUCA world is often depicted as 'chaotic' and 'turbulent' (Kok \& Van den Heuvel 2019; Lawrence 2013). Such descriptions can paint a grim picture. However, leaders who are followers of Christ have an opportunity to help guide people on a journey that is far from grim. It can be a journey filled with God's glory, a journey that offers a different view of this seemingly VUCA world (Van Wynen 2020).

\section{Getting beyond volatile Our volatile world}

The Oxford Online Dictionary (2020) offers numerous descriptions of volatile, including:

$[L]$ iable to change rapidly and unpredictably, especially for the worse. Similar: tense, strained, uneasy, uncomfortable, turbulent, in turmoil, full of upheavals. (n.p.)

The concept of change is closely linked to the concept of volatility. Experts have identified many types of change: disruptive, continuous, remedial, transformative, incremental ... the list continues. Articles on change each have their own 'definitive' list of 3, 5, 12 types of change. The corporate world, technological experts and sociological gurus talk at great length about the accelerating rate of change. Comments such as this are common to most business and leadership journals (Warnock 2018):

Intuitively, the one-two punch of accelerating exponential technology seems a little hard to wrap our minds around. We can observe from the evidence all around us that the pace of technological change is faster than ever before, but it's a little harder to grasp that this record pace of change will accelerate even further ... But, as SU Co-Founder and Chancellor Ray Kurzweil points out, there's even exponential growth in the rate of exponential growth. (n.p.)

Just the repeated use of 'accelerated' and 'exponential' can make some people feel uneasy, uncomfortable, fearful of such a volatile world, fearful of seemingly ceaseless, unbounded change.

\section{Our immutable God}

Consider the descriptions above as you read this description (Barret 2019):

$[H]$ e does not change. Come what may; this God remains the same. He is firm and secure, always there, never fluctuating, incapable of defeat, and forever steadfast as a fortress to those in trouble. (p. 91)

He is the fortress that will not crumble, that cannot be defeated. He is immutable, unchanging and unchangeable. Barrett goes on to describe seven entailments of immutability, saying that it is because God does not change that he is a God of aseity; perfectly united, indivisible (having no parts); all-knowing and all-wise, omnipotent; holy; and he is love (Barrett 2019).
How do we reconcile this immutable God with a volatile world? We do not have to; Jesus already has. Leaders who are followers of Christ need to truly grasp that they are invited to be participants in God's mission, walking with Christ, not taking on a mission of their own on God's behalf. Tennent reminds us that the word mission, though not found in the Bible, was originally used exclusively in reference to the doctrine of the Trinity. It is about God sending his Son and the sending of the Holy Spirit by the Father and the Son. It is about God and his redemptive, historical initiative on behalf of his creation, '... quite apart from any actions or tasks or strategies or initiatives the church may undertake' (2010:54-55). This speaks to the church as a whole - not just individual churches, but also Christian organisations and corporations led by Christian leaders. Our trinitarian God is the reconciler and mission leader in this seemingly volatile world.

\section{Changing perspectives}

Both sudden and continuous change can actually lead to good, bad or merely different outcomes. Even when the change seems for the worse, understanding that God is in charge creates an environment wherein volatile can be reinterpreted, or at least reassessed. The changeable, seemingly volatile, nature of the world may make us uncomfortable, largely because our sense of 'safety' is shaken and we realise that we are not in control. Heath and Heath state that ' $[a]$ mbiguity is the enemy' (2010:53). However, an understanding that God is in control changes everything, including how we perceive change. We may not know the future, but God does. God is all-knowing, and his omniscience is rooted in his immutability (Barrett 2019:100). His immutability is our stability.

\section{Henri Nouwen (1989) wrote:}

Christian leaders cannot simply be persons who have wellinformed opinions about the burning issues of our times. Their leadership must be rooted in the permanent, intimate relationship with the incarnate Word, Jesus, and they need to find there the source for their words, advice, and guidance. (p. 45)

Such leaders can help others see the good that comes from change, even when that change is 'uncontrollable' and unexpected. Or, perhaps, especially because of those factors. They can also help guide their organisations through times of true turmoil and difficulty. Fear and discomfort with the volatility of the world can be tempered by the realisation that he who created, redeemed and sustains us is unchanging and in charge. Leaders who follow him can lead those who follow them into greater assurance of God's presence and into fuller participation in God's mission.

The accelerating pace of change has been noted as a characteristic of VUCA volatility (Forsythe et al. 2018). It is usually assumed that one must try to 'keep up'. What if leaders took time to evaluate and discern what is actually happening in their context and which changes are worth keeping up with? Tim Challies (2007) states: 
When we engage in discernment we attempt to use God's Word to rise above our own limitations so we can see as God sees. Through the truths contained in the Bible, God allows us to see things with His eyes. (n.p.)

What if purpose always informed pace? What if prayer slowed us down and gave us a new perspective? Sound theological and missiological thinking and actions need to ground leaders and their organisations' strategies. It begins with an understanding that God is in charge. Only then will the journey through the seemingly VUCA world begin to make sense.

\section{Surety in uncertainty The journey perspective}

Embracing an understanding of God's mission and considering our participation from the perspective of a journey can help leaders guide their organisations through an often harsh and uncertain VUCA landscape. For most Christian leaders, and followers, waking up to the journey is a critical but gradual and ongoing event. Eugene Peterson noted how, '... so many who understand themselves to be followers of Jesus, without hesitation and apparently without thinking, embrace the ways and means of the culture ...'. He goes on to describe these 'ways of the culture' as being developed in ignorance or in defiance of the ways Jesus uses to lead us as we walk this 'God created-world ... and God-ruled world' (2007:1).

Much of what the VUCA world mindset presents is a product of the impersonal, destructive ways and means of the culture Peterson refers to. The journey concept is a way to think about VUCA in the context of our participation in God's mission. We are journeying both with and toward him, not in the ways of material acquisition and self-satisfaction (Peterson 2007:6). As we have already seen in the previous section, an understanding of being part of God's mission can help change how we perceive a volatile world.

The concept of journey is both metaphorical and literal, but like the rails of a train, the metaphorical and the literal seem to merge on the horizon. In this article we consider both. Alvesson and Spicer argue that metaphors not only help leaders make meaning, but also help them understand contexts and how leadership works in the real world (2011:48). Kok and Jordaan explain and use the term metanarraphor in their article on leadership and mediation in Kok and Van den Heuvel's book on leading in a VUCA world (Kok \& Jordaan 2019):

We continually construct our identity inter-discursively on macromeso and micro levels by telling narratives about ourselves in relation to the world at large and the groups we belong to and use metaphors to bind these narratives into coherent meta-narratives about the self-in-the-world. (p. 521)

This is the source of 'metanarraphor'. The word narraphor is credited to theologian and futurist Leonard Sweet (2015:3). A meta-narrative is an expanded narrative. So, a metanarraphor is an expanded narrative that includes or is conveyed through metaphor.

Niemandt states that ' $[m]$ etaphors allow leaders to draw a picture of possibilities. Narratives shape and form reality, give context and imagination to language and are vital for transformation' (2019b:193). Metanarraphors are the big stories we tell through metaphor. Because metanarraphor provides a way to relate to the world and a way to construct identity, it is imperative that the metanarraphors we choose provide the best possible opportunities to create the identity we are called to portray and help us fulfil the purpose to which we are called. The possibilities of metanarraphors open the way for creating entire new landscapes where leaders and followers can come to new understandings and new, shared points of view. There are numerous metanarraphors that have had a powerful influence on both Christian and secular corporate culture. We will consider a few of these metanarraphors, including journey, as we survey the VUCA environment.

A primary leadership challenge in addressing the VUCA world is to find new ways to think about strategy. Strategy is an attempt to proceed with some measure of certainty into the uncertain future. However, as Harvard Business School Senior Fellow Bill George states, '[t]raditional business methods seem no longer sufficient to address the volume of change we are seeing' (2017). Traditional strategic planning is often seen as inadequate and irrelevant in today's corporate environment. However, it also lacks the theological and missiological depth and breadth needed by Christian organisations. A look at the metaphors we use reveals much about our mindset. Military, sports and machine metaphors, primarily from the 19th and 20th centuries, have had significant influence and have shaped strategy in both secular and Christian organisations, but they do little to reflect biblical principles, 'create new landscapes' or encourage 'new, shared points of view'.

\section{Military metaphors}

In his book Strategy: A History, military historian Lawrence Freedman tracks strategy's etymology back to classical Greek, saying the common reference, on through the Middle Ages and into the modern era, was the 'art of war' (2013:130). Freedman shows the influence of military metaphor in policy and practices throughout the history of strategy, from battlefields to boardrooms. Mintzberg also cites the military origins of strategy and mentions that there was a 'director of strategic planning' 2400 years ago, according to a loose translation of Sun Tzu's Art of War (2013:5). For whatever good it does or does not do, the metanarraphor construct of strategy as warfare is extensive. There are targets, tactics, ground to be taken, troops to rally, turf to defend, beachheads to establish, shares to capture and plans to execute.

Military terms multiplied as the globe faced two world wars. They also became more prominent in Christian contexts (beyond the spiritual warfare terminology in 
scripture) when, in the 1950s, many of those who had served in World War II became the new wave of global missionaries. Both Bosch and Newbigin address the mentality of the church and the influence of military language from even earlier times (Bosch 1979):

The optimism and the military terminology that were, for so long, typical of the missionary enterprise of both Roman Catholics and Protestants, are indicative of this mentality. At the World Missionary Conference in Edinburgh (1910) to take but one example, the terms that were used again and again included the following: soldiers, forces, advance, army, crusade, marching orders, strategy, planning, and many more. And even when we do not (today) use this terminology, our conduct often reveals a comparable mentality. (p. 31)

The terminology did not fade as much as Bosch might have hoped. Newbigin (1995) points out:

Significant 'advances' of the church have not been the results of our own decisions about the mobilizing and allocating of 'resources'. This kind of language, appropriate for a military campaign or a commercial enterprise, is not appropriate here ... for the mission is not ours but God's. (p. 889)

The corporate world has concerns as well. Audebrand, speaking on business strategy, notes that: '[w]hile various metaphors have waxed and waned in popularity over the years, the war metaphor still guides strategic management theory, research, and education' (2017:1). He states that a reappraisal of the metaphor is long overdue.

\section{The language of sports}

The phenomenon of VUCA is not only 'attacked' but also 'tackled'. The competitive or combative approach to leadership is apparent in the sports and game metaphors that permeate the language of business and strategy: the ball is in their court; slam dunk; down to the wire; ballpark figure; cover the bases; step up to the plate; dropped the ball; goal posts; fumble; game plan; level the playing field; end run; let your guard down; stalemate. Business consultants talk about needing new 'playbooks' to deal with VUCA, how to 'checkmate complexity' and about agility and needing to 'pivot quickly' (Horvath 2016:2).

Philosophy professor Maurice Hamington lists four potential 'harms' derived from the business-as-games metaphor: 'compartmentalized morality, truncated ethics, trivialized stakes, and the privileging of adversarial relationships' (2009:477). Hamington says that game rules have no allowances for generosity, helping and so on but only see adversaries, creating an us-and-them dichotomy. And with their clear beginnings, middles and ends, they encourage short-term thinking (2009:578-581). Hamington clarifies that he is not saying that one should never use any of these metaphors, but that one should be attentive to language because words matter. He also suggests developing alternative metaphors. Journey is one of his suggestions (2009:483). Many sports metaphors do not communicate well in today's globalised contexts. Different cultures play different sports. Sports and game metaphors commonly create and foster a competitive, rather than collaborative, environment. Living in such a metanarraphor also encourages business leaders to try to 'beat' VUCA.

\section{Industrial strength}

The language of machines and empire building is another metanarraphor common to organisations. Morgan, in his classic book Images of Organization (1996), lists the machine metaphor as one of eight key organisational metaphors. As the science of strategic planning came into prominence in the first half of the 20th century, its language took on the nature of the context into which it was born. It was an era of powerful new machines, city skylines on the rise, ever-faster and widerreaching transportation and communication, streamlined manufacturing processes and sweeping social change. Building and construction metaphors told the story of burgeoning brickand-mortar financial empires. Production-line metaphors told the story of automation and efficiency. The images of steam engines, steel, money and men, cogs and wheels told stories of power.

Just as warfare and game strategy metaphors reflect philosophies of conflict and competition, machine metaphors reflect a philosophy as well. They grew out of the Industrial Age, ruled by logic, science and extreme rationality. There was a process for everything, and that process was enacted according to reason. Mintzberg states, 'an emphasis on formal rationality permeates the literature of planning' (2013:13). It was considered the only way to accomplish one's goals and was integrally connected to self-interest, mechanisation and the survival of the fittest. Mintzberg continues: 'In fact, the key, if implicit, assumption underlying strategic planning is that analysis will produce synthesis' (2013:13). He argues that this is the 'old "machine"' assumption. If every component is produced by a machine and assembled in order, an integrated product will appear at the end of the line. 'This analogy has influenced some of the most important thinking in the field of planning, and has proved to be patently false. Organisational strategies cannot be created by the logic used to assemble automobiles' (2013:13).

And yet ... the big machine metaphors and building metaphors live on. Command and control are still major factors in this mechanistic approach, as projects are expected to move sequentially from one clearly defined stage to the next. We have figurative blueprints, foundations, frameworks, platforms, planning cycles, supply chains and corporate ladders. People speak of 'structures' and 'architecture' that have nothing to do with the office building in which they might be sitting. Add the elements of input, output and outcome, and we have ridden the whole production line. There are even ' $[p]$ illars for change' to address VUCA (Horvath 2016:1). Such a phrase points out, however, that the VUCA world mindset is actually at odds with such metaphors and the thinking and practices they represent. However, even in the face of the constant demand for change and innovation, many organisations and corporations cling to the remnants and ruins of their factories and forts. 


\section{Reorientation}

It is not just the VUCA world context that calls for change. Bosch called for a major reorientation of thinking in his chapter, 'The Emergence of the Post-Modern Paradigm'. This included moving away from a mechanistic view of mankind, a re-evaluation of power and of technology, a reaffirmation of the indispensableness of commitment and conviction, and the retrieval of togetherness and interdependence (1991:313-345). Thirty years later, we have changed, but have we changed enough to be able to address the VUCA world challenges of this century in the way Bosch envisioned? Is innovation an answer, a symptom or a response? Are we adequately addressing these issues from a theological perspective?

Through the centuries, God calls his people to participate with him. However, this privilege is not a command to 'take over'. Mission is not 'our task'. It is God's mission, and it will be accomplished according to his will and ways. Tennent (2010) states that missiology has been dominated by the social sciences and that, whereas the social sciences provide many helpful insights, missiology is a part of Christianity as a whole. It has an entirely different worldview and foundation. However, '... churches and mission agencies have increasingly taken their cue from the business world rather than biblical models rooted in Scripture and arising out of theological reflection' (2010:410). Tennent continues, emphasising how this has led to consumerdriven, competitive churches and mission agencies that favour customer satisfaction over theology, social sciences over missiology and pragmatism over biblical reflection. He says that this enterprise is then 'sprinkled with Christian jargon to give it a thin veneer of theological and biblical plausibility' (2010:410). It is the same consumer-driven mentality that feeds into the VUCA world thinking.

Tennent is not alone in his concerns. Bosch (1991) detailed how the church, conservative and liberal, premillennialist and post-millennialist, those of almost all labels in Christian society from the 20th century onward, adopted the business practices of secular corporations (1991:313-345).

Rather than just struggling alongside secular corporations as they scramble through their brick-and-mortar rubble looking for answers to what are seen as the new realities of a VUCA world, Christian leaders can set an example. They have an option beyond the false certainty of previous eras and the uncertainty of the current era. They know where their surety can be found. Eugene Peterson (2007) expressed it eloquently:

[Jesus] shows the way. He also is the way. He doesn't point out the way and then step aside and let us get there on our own as best we can. Jesus points out the way, but then he takes the initiative inviting us to go with him, taking us with him across land and sea, through all kinds of weather .... (p. 36)

As we look at the privilege and responsibility of the church to participate with God in his mission, we come to see that listening, watching, prayer, discernment, relationships and obedience take precedence over any attempts at organisational strategy or planning. Any strategies or plans that might emerge from these reflective practices would have the goal of alignment with God's leading and direction. We may remain uncertain in that we do not know what all the future holds, but we can also remain certain that God knows and is in control. Increasing in knowledge and wisdom concerning God and the things of God will allay the fears associated with uncertainty.

Warfare, sports, machines and buildings all provide imagery that can communicate effectively in specific situations. However, wars and games are lost. Machines and buildings wear out, break down and fall apart. There is no certainty to be found there. What metanarraphor will we live in? What stories will our lives tell? The concept of a journey in which we are following Christ, seeking to know him better and trusting his leadership can help us see the VUCA world from a whole different vantage point (Van Wynen 2020:267-280). God is in control, and God is in the lead. As leaders, our certainty is in the one we follow.

\section{Calm amidst complexity}

Complexity, the third of the VUCA characteristics, sends leaders scrambling to restructure and to develop new resources (Bennett \& Lemoine 2014) for coping with this heavyweight chunk of reality. Complexity can be described as the increasing interconnectedness and density of networks - technical, processes, tools, systems, infrastructures, products, services and relationships. It is one of the reasons change is needed, and change in turn often increases complexity.

Articles and books abound on how to reduce, cope with, manage, eliminate or conquer complexity. Nason, in his book It's Not Complicated, points out that people often confuse complicated with complex. He deftly explains the difference and warns against approaching the complex with solutions suited for the merely complicated. He states that complicated problems can be hard to solve but are addressable with rules, systems and processes. Complex situations, however, involve too many unknowns and too many interrelated factors to reduce to rules and processes (Nason 2017). Like its VUCA companions volatility and uncertainty, complexity can leave leaders feeling that situations are out of their control. However, again, the questions arise. Who should be in control? And what is it that needs controlling?

\section{The terror and taming of complexity}

Author Marilynne Robinson (1998) eloquently depicts what happens when we lose sight of what is important:

$[W]$ e act as if the reality of economics were reality itself, the one Truth to which everything must refer. I can only suggest that terror at complexity has driven us back to this very crude monism. We have reached a point where cosmology permits us to say that everything might in fact be made of nothing, so we cling to the idea that something is real and necessary, and we have chosen, oddly enough, competition and market forces, taking refuge from the wild epic of cosmic ontogeny by hiding our head in a ledger. (p. 4) 
Robinson's phrase 'terror at complexity' sounds dramatic, but perhaps only a feeling as strong as terror could drive entire civilisations to become so narrowly focused.

Complexity is sometimes ignored or misinterpreted, as noted above, but has also, in some quarters, been given great attention. Complexity theory, birthed in the world of computer science, spread to the world of natural sciences and then to management and organisational studies. It focuses on complex systems with numerous interacting parts, which often give rise to unexpected order. Straub notes, however, that complexity theory has not drastically changed how organisations do business. Whilst literature and discussions on complexity, particularly 'the butterfly effect' (the flapping of a butterfly's wings in one place can cause changes on the other side of the world), alerted leaders to the idea of interconnectedness, Straub states that managers desiring control found complexity inconvenient (2013).

\section{Clarifying complexity}

How can Christian leaders approach complexity from a missional, journey-focused perspective? One, on a journey there is likely to be a more natural acceptance of complexity. Journeys, by nature, are complex. Each day, there are decisions to make depending on the destination, terrain, weather, resources needed, your preparedness and the preparedness of those who travel with you. Many of these decisions involve interrelated factors that you cannot control.

Journeys also usually involve relationships: traveling companions, those you meet along the way, people back home. The relationships in a missional journey begin, as expected, with God. He will neither ignore, nor be confounded by, complexity. He is the author of complexity yet is in himself simple (Bavinck 2004:173-177). Just as he is the unchanging God in a changing world, in his aseity and simplicity he is the Creator of all things. His creation is beautifully complex, and he commands and comprehends it fully (Barrett 2019:71-88). Much of the time, we will begin to see the patterns and paths he lays out for us (though often one step at a time). And when we cannot see, we can still trust and follow, walking in his footsteps.

\section{Walking through complexity}

Christ entered the world during a tumultuous and complex time in history. How did he deal with kingdoms and powers, the constant press of the crowds, oppression and prejudice, misconceptions, injustice, sickness and sin? He showed compassion, and he walked. He spent time with his Father. He spent time with people. He prayed. He ate with family, friends and the worst of sinners. He loved the unlovable. He taught, and he walked.

There is a lot in Scripture about walking. Although we are well aware that there were fewer transportation options in Bible times, walking still has a certain purposeful appeal and great value. It allows for companionship, conversation, reflection, appreciation of creation, varied pacing and refreshment.

An often-recited essay entitled 'One Solitary Life', usually attributed to James Allan Francis (1864-1928), describes Jesus' life as one of obscurity and says, '[ $h]$ e never traveled two hundred miles from the place where He was born' (Francis 2016). This idea of Jesus sticking close to home, popularised by others as well, is a bit misleading. One, he was far from home just in the fact that he came to Earth. Two, though Jesus may not have travelled vast distances, it is estimated that he walked a minimum of 15000 miles in his lifetime on Earth (Hargis 1998). So, whilst the essay makes its point that Jesus did not do many things the world associates with greatness, Jesus was definitely on a journey and put in a lot of miles. His physical journey was primarily on foot. There were occasional boat rides and at least one donkey, but most of Jesus' days were spent walking together with his disciples and, often, great crowds.

In the VUCA world, many speak to the need for speed, innovation and urgency to keep up with the pace of change. However, it is perhaps more important to remember the value of walking. In the VUCA world of complexity and interconnected cause and effect, it is also important to remember the value of relationship. Though many focus on the complexity of systems and technology in our current era, there is also the complexity of relationship. Theologian and missionary Kosuke Koyama (1979) wrote a book of reflections entitled Three Mile an Hour God:

God walks 'slowly' because he is love. If he is not love he would have gone much faster. Love has its speed. It is an inner speed. It is a spiritual speed ... It goes on in the depth of our life, whether we notice or not, whether we are currently hit by a storm or not, at three miles an hour. It is the speed we walk and therefore it is the speed the love of God walks. (p. 7)

Koyama also said that at the cross, Jesus was not even going at three miles an hour. He was 'full stop' (1979:7). The veil was torn, the mystery revealed. The cross and the risen Christ brought new access, new clarity (Heb 10:19-22). And this is what makes our journey possible, whatever complexities may lie before us. God is in control, leading the way and bringing clarity.

\section{Traversing ambiguity}

The final characteristic of VUCA is ambiguity, the quality of being open to more than one interpretation; inexactness. Bennett and Lemoine offered this description: 'No precedents exist; you face "unknown unknowns"' (2014:27). Again, we see this theme of lack of control. And there is a double 'unknown', which implies that people are feeling seriously frustrated and unable to even create potential scenarios. Ambiguity makes it difficult to determine if you have made the best decision, set up the right metrics and quotas, or reached your goal. Ambiguity makes it difficult to do 'business as usual'. And yet, so much of life is seemingly ambiguous. 


\section{Holding on and letting go}

There it is again. Control. How to overcome ambiguity and gain control. The experts present all sorts of leadership advice. George recommends 'VUCA 2.0' (2017). Horvath advises start-ups to grow fast and 'diminish uncertainty' and tells established organisations to focus on 'reducing ambiguity' through policies, procedures and metrics (2016:2). Others say to restructure, be prepared, experiment and invest in information (Bennett \& Lemoine 2014:27). Still others recommend changing corporate culture and developing leadership skills such as integrity, empowerment (Forsythe et al. 2018), courage and understanding (Gruwez 2017). These may all be useful ideas, but they are not new ideas.

The lack of truly new advice or ideas again raises the questions, is VUCA new? When was the world not VUCA? The world may be VUCA for different reasons, or in different circumstances. The main characters and the contexts have changed, but VUCA is not new. This does not, however, invalidate the concept or the need for a different approach. If anything, the concept of ongoing VUCA demonstrates how, deep down, people realise that we are on a journey. They may prefer to think of VUCA as a phase or a paradigm, but to acknowledge VUCA is to acknowledge ongoing change. The premise that every era is a VUCA era actually reinforces the idea that we are on a journey; VUCA is just part of the terrain and today's weather forecast.

Ambiguity will not go away in the face of having a plan. There will always be inexactness, multiple choices, numerous perspectives. An advantage for leaders following God, however, is that he does know the right way, the best choice, the plan (the big picture and the smallest details) (Lewis 1965):

$[A] 11$ that is made seems planless to the darkened mind, because there are more plans than it looked for ... There seems no plan because it is all plan, there seems no center because it is all center. (p. 218)

God is at the centre, all-seeing, all-knowing. And he will direct our paths.

John Stott once wrote: 'Insistence on security is incompatible with the way of the cross' (1986:288). That relates not only to our safety, but also to that on which we depend. For the Christian, God - not jobs, processes or institutions - is the source of stability. This enables optimism in the face of hardship, peace in times of uncertainty, surety even though the future is unknown. It means a quiet walk by the cool waters before facing the next rough VUCA trail, the next seemingly ambiguous fork in the road. Someone far greater than you is in charge, in the lead, providing clarity and giving direction.

\section{Missional intent}

Recognising that God is in control and giving direction does not mean that we have no role to play. Ambiguity may always be with us, but discerning our missional intent under
God's direction will reveal our next steps forward. Dietrich Bonhoeffer (2008) wrote:

[E]ach moment, lived in God's sight, can bring an unexpected decision. Thus, only one thing can be repeated again and again, also in our time: in ethical decisions a man must consider his action sub specie aeternitatis [in light of eternity] and then, no matter how it proceeds, it will proceed rightly. (p. 368)

Considering our actions in light of eternity: This is not a new idea, either. However, it is an overlooked and neglected idea. It means purposefully seeking God's will and direction, thinking of the long-range, even eternal, implications of what we do. Rather than leaping into strategies to fight, master, overcome or otherwise deal with a VUCA world, discerning missional intent is perhaps a better step. Missional intent describes the fruit of an ongoing discernment process. Missional intent is about listening, learning and living the journey under God's direction (Van Wynen 2020). It is about walking with Christ and discerning how he wants us to participate with him in his mission. The process of discovering an organisation's missional intent is one of exploration, prayer, reflection and discernment to identify areas of focus and concentration. Goals and action steps related to missional intent are developed along the way. Because this is a part of the journey, there is constant observation of context and a requisite flexibility to adapt, change and adjust as needed. In an organisation, this ongoing process is ideally the responsibility of a team of missional leaders, leaders who are, as described by Kirk Franklin (2017:150):

- discerning with the Holy Spirit and God's community what God is doing in the world

- dwelling in God's Word and living within the narrative of Scripture

- imagining what God wants to do in the world

- experiencing an inner transformation of [themselves] and those [they] lead.

Such leaders are attuned to God's leading, work well together, exercise accountability and have a good interconnected network with the broader body of their church or organisation. Niemandt defines missional leadership as 'the transformation of people and institutions to participate, through meaningful relations and in the power of the Spirit, in God's mission' (2019a:1137). Niemandt also relates missional leadership to the journey, characterising it as relational and spiritual, and commenting that missional spirituality is a spirituality for the road (reflecting on Bosch's book of the same title). It is robust enough to be carried into everyday life (Niemandt 2014). Leaders such as these are equipped to address VUCA issues.

Joubert states that ' $[l]$ eaders urgently need new narratives derived from an entirely new understanding of self, others and reality' (2019:3329). A journey mindset and heart are a possible way forward. The journey concept allows for flexibility, yet is stable in its dependence on Christ. It can provide not only freedom of movement, but also freedom from the feeling that the world is spinning out of control, freedom from the compulsion to unceasingly increase speed and innovation. A survey conducted among more 
than 50 mission leaders around the world demonstrated how people across cultures and contexts easily related to the concept of journey. The survey also revealed that an understanding of journey includes an assumption of change, ups and downs, and many unknowns (Van Wynen 2020). Living within a missiologically sound journey concept means that one becomes accustomed to progress and setbacks, spectacular horizons and frustrating detours. Ongoing change is one of the life signs of a journey.

Leadership books and articles often talk about control, whether single-handed or shared. It might serve better and be more realistic to talk about responsibility rather than control. Responsibility relates to stewardship and commitment. Control assumes power. However, both power and control are fleeting, and often even fictitious. Peter Bernstein notes: 'The past seldom obliges by revealing to us what wildness will break out in the future' (1996:334). Determining your missional intent helps you focus on what you are supposed to be doing and who you are supposed to be (personally or corporately) whilst leaving flexibility for change, growth and adjustments to the how. Most importantly it welcomes the direction of our totally in control, but untamed, God. 'It is the incontrovertible teaching of Scripture, however, that in God's secret being he is unknowable and unnamable' (Bavinck 2004:2/133). This same 'unknowable' God desires to lead and guide us and make himself known as far as we are capable of understanding. Determining missional intent is seeking his leadership that we may be a blessing, rather than seeking his blessing on our own plans. $\mathrm{He}$ is in charge, leading, clarifying and directing.

\section{Conclusion: Courage to follow, courage to lead}

What can Christ-following leaders offer a VUCA world? How can they lead their organisation in a VUCA environment?

\section{Follow first}

The Christian leader sees and responds to the VUCA world differently. With an understanding of God's mission, a desire to participate and a recognition of being on a journey with God, the world is not nearly as out of control as some imagine. However, the leader must first be a follower, walking with Christ, knowing the One he or she follows.

Niemandt looks at leadership for the missional church as primarily focused on following. He states: 'Jesus does not call leaders, but calls followers to follow him .... This church, as a band of faithful followers, is called by the Spirit to be on a journey with God' (2019a:1626). This is not just a call to individuals or churches, but to all believers as a united body.

\section{Reflect and respond rather than react}

Christopher Wright (2006) states:

The ethical challenge to God's people is, first, to recognize the mission of God that provides the heartbeat of their very existence and, then, to respond in ways that express and facilitate it rather than deny and hinder it. (p. 357)

This is the core of missional leadership.

Living in a metanarraphor that focuses on warfare, competition or building an empire may do more to hinder rather than facilitate. However, living within a journey with God, the Christian leader is better able to respond to God's mission in a VUCA-labelled world. Missional leadership is more than a particular perspective. It is allencompassing, 360 degrees and beyond, taking in the here and the hereafter. This is not just 'spiritual talk'. Yes, it is spiritual, but there is nothing more practical, more applicable, more necessary to our journey than spiritual life and direction. In the face of VUCA, or VUCA mindsets, we do not withdraw. We do not 'wait it out'. We fully engage, but we do so fully aware that God's vantage point is far beyond anything we can envision, and yet he makes the way available to us through his most gracious leading.

\section{Lead courageously}

Kegan and Lahey note: 'It is not change that causes anxiety; it is the feeling that we are without defenses in the presence of what we see as danger ...' (2009:49). Knowing that we do have defences changes how we feel about change, changes how we feel about and respond to the VUCA world mindset. It takes courage for a leader to respond to a question with, 'I don't know. Let's explore this together'. Niemandt offers a more comprehensive look at the role of courage (2019a:177-181). As he reflects, discernment can lead to all sorts of new learning about ourselves and God, 'but demands prophetic courage' (2019a:113). The courage comes from knowing God is in charge, leading, clarifying and directing. Because of what God does, the leader who is following God has the privilege of helping create an environment wherein God's people can be encouraged and respond to his leading, rather than give in to the rush and confusion of the world around them (Ps 102):
Of old you laid the foundation of the earth,
and the heavens are the work of your hands.
They will perish, but you will remain;
they will all wear out like a garment.
You will change them like a robe, and they will pass away,
but you are the same, and your years have no end.
The children of your servants shall dwell secure;
their offspring shall be established before you. (vv. 25-28)

\section{Acknowledgements Competing interests}

The authors declare that they have no financial or personal relationships that may have inappropriately influenced them in writing this research article. 


\section{Authors' contributions}

This research flows from research done for a PhD. The fieldwork, research and write-up were done by S.E.v.W., and C.J.P.N. served as research supervisor and contributed editorial and contextual content, as well as creative input.

\section{Ethical considerations}

Ethical clearance was granted by the Ethics Committee of the Faculty of Theology and Religion of the University of Pretoria.

\section{Funding information}

This research received no specific grant from any funding agency in the public, commercial or not-for-profit sectors.

\section{Data availability statement}

Data sharing is not applicable to this article as no new data were created or analysed in this study.

\section{Disclaimer}

The views and opinions expressed in this article are those of the authors and do not necessarily reflect the official policy or position of any affiliated agency of the authors.

\section{References}

Alvesson, M. \& Spicer, A., 2011, Metaphors we lead by: Understanding leadership in the real world, Routledge, New York, NY.

Audebrand, L., 2017, 'Sustainability in strategic management education: The quest for new root metaphors', Academy of Management Learning and Education 9(3) viewed 23 November 2019, from https://journals.aom.org/doi/10.5465/ amle.9.3.zqr413

Barrett, M., 2019, None greater: The undomesticated attributes of God, Baker, Grand Rapids, MI.

Bavinck, H., 2004, Reformed dogmatics, volume two: God and creation, Baker, Grand Rapids, MI.

Bennett, N. \& Lemoine, G.J., 2014, 'What VUCA really means for you', Harvard Business Review, Jan-Feb 2014, viewed 20 June 2019, from https://hbr. org/2014/09/a-framework-for-understanding-vuca/.

Bennis, W., 2000, Managing the dream: Reflections on leadership and change, Perseus, Cambridge, MA.

Bernstein, P.L., 1996, Against the gods: The remarkable story of risk, John Wiley and Sons, Inc., New York, NY.

Bonhoeffer, D., 2008, Works - Barcelona, Berlin, New York: 1928-1931 Vol 10, Fortress Press, Minneapolis, MN.

Bosch, D.J., 1979, A spirituality of the road, Wipf and Stock, Eugene, OR.

Bosch, D.J., 1991, Transforming mission, Orbis, New York, NY.

Challies, T., 2007, Defining discernment, viewed 17 April 2020, from https//www. challies.com/articles/defining-discernment.

Forsythe, G., Kuhla, K. \& Rice, D., 2018, 'Understanding the challenges of the VUCA environment', Chief Executive, May 15, 2019, viewed 15 February 2020, from https://chiefexecutive.net/understanding-vuca-environment/.

Francis, J., 2016, Tullylish parish - One solitary life, viewed 07 August 2019, from http://www.tullylish.com/greetings/christmas/85-reflections.

Franklin, K., 2017, Towards global missional leadership, Regnum, Oxford.

Freedman, L., 2013, Strategy: A history, Oxford University Press, New York, NY.

George, B., 2017, 'A strategy for steady leadership in an unsteady world', Harvard Business School, viewed 21 March 2020, from https://hbswk.hbs.edu/item/ a-strategy-for-steady-leadership-in-an-unsteady-world.
Gruwez, E., 2017, VUCA world: A quick summary, September 2017, viewed 29 March 2020, from https://tothepointatwork.com/article/vuca-world/.

Hamington, M., 2009, 'Business is not a game: The metaphoric fallacy', Journal of Business Ethics 86(4), 473-484. https://doi.org/10.1007/s10551-008-9859-0

Hargis, M., 1998, On the road - The inns and out of travel in first century Palestine, viewed 13 June 2019, from https://www.christianitytoday.com/history/issues/ issue-59/on-road.html.

Heath, C. \& Heath, D., 2010, Switch: How to change things when change is hard, Currency, New York, NY.

Horvath, P., 2016, Leadership in a time of VUCA-four pillars for change and innovation leaders, viewed June 2019, from https://luman.io/leadership-time-vuca-fourpillars-change-innovation-leaders/.

Joubert, S., 2019, 'A well-played life: Discernment as the constitutive building block of selfless leadership', in J. Kok \& S. Van den Heuvel (eds.), Leading in a VUCA world: Integrating leadership, discernment and spirituality, pp. 3284-3553, Springer, Cham.

Kail, E., 2011, 'Leading effectively in a VUCA environment', Harvard Business Review 1 , viewed 17 November 2019, from https://hbr.org/2010/11/leading-in-a-vucaenvironment.html.

Kegan, R. \& Lahey, L., 2009, Immunity to change, Harvard Business Review Press, Boston, MA.

Kok, J. \& Jordaan, B., 2019, 'The metaphors we lead and mediate by: Insights from the cognitive metaphor theory in the context of mediation in a VUCA world', in $\mathrm{J}$. Kok \& S. Van den Heuvel (eds.), Leading in a VUCA world: Integrating leadership, discernment and spirituality, pp. 204-830, Springer, Cham.

Kok, J. \& Van den Heuvel, S., 2019, Leading in a VUCA world: Integrating leadership, discernment and spirituality, Springer, Cham.

Kotter, J.P., 1999, What leaders really do, Harvard Business School Press, Boston, MA.

Koyama, K., 1979, Three mile an hour God, Orbis Books, Maryknoll, NY.

Lawrence, K., 2013, Developing leaders in a VUCA environment, UNC Executive Development, viewed 16 July 2020, from www.execdev.unc.edu.

Lewis, C.S., 1965, Perelandra, MacMillan Publishing Company, New York, NY.

Mintzberg, H., 2013, The rise and fall of strategic planning, Free Press, New York, NY. Morgan, G., 1996, Images of organization, Sage Publications, Inc., Thousand Oaks, CA.

Mortimer, I., 2014, What century saw the most change?, History Extra (BBC), viewed 05 January 2020, from https://www.historyextra.com/period/norman/whichcentury-saw-the-most-change/.

Nason, R., 2017, It's not complicated: The art and science of complexity in business, Rotman-UTP Publishing, Toronto, ON.

Newbigin, L., 1995, The open secret, rev. edn., William B. Eerdmans, Grand Rapids, MI.

Niemandt, C.J.P., 2014, 'Developing missional congregations', Paper presented at Council for World Mission African Regional Assembly, viewed 21 November 2019, from https://www.academia.edu/8028751/Developing_missional_congregations paper_delivered_at_the_Council_for_World_Mission_African_Assembly.

Niemandt, C.J.P., 2019a, Missional leadership, AOSIS, Cape Town.

Niemandt, C.J.P., 2019b, “Narraphors" in missional transformation of South African denominations: A herd of buffaloes', in S. Jung, V. Kessler, L. Kretzschmar \& E. Meier (eds.), Metaphors for leading - Leading by metaphors, pp. 187-199, V\&R Unipress, Göttingen.

Nouwen, H., 1989, In the name of Jesus, The Crossroad Publishing Company, Chestnut Ridge, NY.

Oxford Online Dictionary, 2020, 'volatile', Lexico, viewed 04 April 2020, from https:// www.lexico.com/definition/volatilecom/.

Peterson, E.H., 2007, The Jesus way, William B. Eerdmans Publishing, Grand Rapids, MI. Robinson, M., 1998, The death of Adam, Picador, New York, NY.

Stott, J., 1986, The cross of Christ, InterVarsity Press, Downers Grove, IL.

Straub, R., 2013, 'Why managers haven't embraced complexity', Harvard Business Review, May 2013, viewed 03 January 2020, from https://hbr.org/2013/05/whymanagers-havent-embraced-complexity.

Sweet, L., 2015, From tablet to table, NavPress, Colorado Springs, CO.

Tennent, T., 2010, Invitation to world missions: A Trinitarian missiology for the 21st century, Kregel Academic \& Professional, Grand Rapids, MI.

Tovar, P., 2016, 'Leadership challenges in a V.U.C.A. world', Oxford Leadership, viewed 07 December 2019, from http://www.oxfordleadership.com/leadershipchallenges-v-u-c-world/.

University of Bologna, n.d., viewed 16 March 2020, from https://www.unibo.it/en/ university/who-we-are/our-history/university-from-12th-to-20th-century.

Van Wynen, S., 2020, 'A journey of missional intent: Organizational strategy in the context of God's mission', PhD thesis, Biblical and Religious Studies in the Faculty of Theology and Religion, University of Pretoria.

Warnock, C., 2018, 'Exponential technology continues to accelerate-but why?', Singularity University Blog, December 24, 2018, viewed 04 April 2020, from https://su.org/blog/exponential-technology-continues-to-accelerate-but-why/.

Wright, C.J.H., 2006, The mission of God, InterVarsity Press Academic, Downers Grove, IL. 